\title{
Reverse Payments - Life After Actavis
}

\section{Daryl Lim}

Published online: 20 December 2013

(C) Max Planck Institute for Intellectual Property and Competition Law, Munich 2013

On its face, the United States Supreme Court's opinion in Federal Trade Commission (FTC) v. Actavis seemed to contain the elements of a straightforward antitrust indictment: a dominant drug company paid potential rivals millions of dollars not to compete at the cost of public access to cheaper medicine. The interests of these rivals, once aligned with those of the public, have been twisted to align with its former rival and current paymaster. According to an FTC report, these settlements cost consumers $\$ 3.5$ billion a year.

The Court likened these settlements to cases involving market division arrangements, hardcore offenses normally weeded out under a per se standard of illegality. However, it ultimately opted for a rule of reason approach. Lower courts were to balance benefits and anticompetitive harms, taking into consideration the size and scale of the payment in relation to the patent owner's anticipated litigation costs and any auxiliary services it received from the generic drug company. Large and unexplained payments could be used as a proxy for market power and anticompetitive harm, sparing lower courts the need for complex, costly and timeconsuming inquiries into issues of patent validity and infringement.

The Court pointed accusingly to the Hatch-Waxman Act, so named after its legislative sponsors, as a significant reason for these settlements. Ironically, the Act was enacted to accelerate the entry of generic drugs into the market. It allows generics to piggy-back on the prior regulatory approval obtained by brand-name drugs without undertaking costly and time-consuming clinical trials of their own, if the generic drugs contained the same active ingredients and were bioequivalent.

In the interest of full disclosure, I am a signatory to the Brief Amici Curiae of 118 Law, Economics, and Business Professors and the American Antitrust Institute in Support of Petitioners in F.T.C. v. Actavis, Inc., 133 S.Ct. 2223 (2013).

D. $\operatorname{Lim}(\bowtie)$

Assistant Professor

The John Marshall Law School, 315 South Plymouth Court, Chicago, IL 60604, USA

e-mail: daryllim@jmls.edu 
Under a "Paragraph IV" filing, a generic can avoid waiting until the pioneer's patent expires by showing that the patent was invalid or not infringed by the manufacture, use or sale of the generic's drug.

To entice generic challengers to step into the arena, the first-filing generic wins 180 days of shared exclusivity in the marketplace with the patent owner. The brand is able to obtain a 30-month stay on generic approval, and no other generics can enter during the first filer's 180-day period. With the marginal cost of drug manufacture being almost negligible, and with little or no generic competition (unless simultaneous generic filing occurs), that period assures the first filer a bountiful windfall. Indeed, the Court noted that most of the generic's profits for the drug were made during that period. Herbert Hovenkamp observed that under these circumstances, a rational first filer would only accept a payment to settle that was at least as great as the expected value of production. Further, most first filers bear no risk of being liable for damages even if they lose, unless they have begun manufacturing before they win the challenge. While the Hatch-Waxman Act makes it lucrative for generic challenges to induce settlements, the fact that the European Union faces similar issues in cases such as Lundbeck, Les Laboratoires Servier and others even without similar legislation is evidence that reverse payments occur outside the setting of the Act.

Chief Justice John Roberts observed in his dissent that even seemingly iron-clad patents could hide an Achilles' heel. Risk-adverse, even risk-neutral, patent owners may willingly pay for peace of mind, even if they thought that the generic's chances of success were slim. The right to settle was therefore merely a corollary of the right to litigate. Patents, the Chief Justice pointed out, essentially create an antitrust-free zone within their scope. Only in narrow instances such as sham litigation and fraudulent patent procurement would antitrust scrutiny be warranted. Otherwise lower courts would end up caught in a web of "turducken" ${ }^{1}$ trials - where issues of validity and infringement had to be litigated as intermediate steps to assess whether a settlement passed muster under what the Chief Justice called "antitrust law's unruly rule of reason." This, he warned, would be "time consuming, complex and expensive," and "not worth the litigation candle." The merit in these arguments carried the day in many of the lower courts' decisions up to that point.

While having the appeal of simplicity, this "scope of the patent" approach assumes away the issues of validity and scope central to the Hatch-Waxman challenge. Mark Patterson noted that while patent owners have exclusive rights over the invention, those rights do not extend to information about patent validity, and that applying the "scope of the patent test" elevates a procedural presumption of validity into a substantive rule. The rule in effect prevents other validity challenges whether or not the patent itself is worthless. Patents are what have been called "probabilistic" rights, with studies showing as many as half of those litigated being found invalid. Scott Hemphill and Bhaven Sampat revealed that many settlements involve patents covering new formulations and delivery mechanisms rather than pioneer molecules. An FTC study showed generics won Paragraph IV challenges

\footnotetext{
${ }_{1}$ A dish where a boneless chicken is stuffed into a boneless duck, and in turn stuffed into a turkey.
} 
$73 \%$ of the time between 1992 and 2000. Subjecting patents to scrutiny would help weed out bad ones, whether seemingly ironclad or not.

In any case, the Chief Justice's concern over the rule of reason's complexity may be overstated. Antitrust analysis is based on analyzing counterfactuals and is inherently speculative to some degree. Where there is cause for suspicion, burden shifting may give courts the best opportunity to reach a correct outcome efficiently. Aaron Edlin, Scott Hemphill, Herbert Hovenkamp and Carl Shapiro point out that burden shifting is common in rule of reason cases, and is particularly appropriate in reverse payment cases since the defendants possess the relevant evidence. Moreover, they say, the complexity is the result of the defendants' own actions.

The Court of Appeals for the D.C. Circuit recognized as much in U.S. v. Microsoft. It candidly observed that neither the parties nor the court can confidently reconstruct a counterfactual world. Because defendants are left to shoulder the uncertain consequences of their own undesirable conduct, the relevant question is instead whether the exclusion of nascent threats was reasonably capable of contributing significantly to a defendant's continued monopoly power at the relevant time.

Further, Andrew Gavil, William Kovacic and Jonathan Baker observed that courts do not actually balance procompetitive justifications against anticompetitive effects. As long as plausible justifications are proffered, courts usually exonerate the antitrust defendant. And with respect to reverse payments, if validity and infringement become an issue, a trial judge will be well placed to determine the strength of the patent relative to the size of the payment by the time he or she has construed the claims. Studies by Einer Elhauge and Alex Krueger also show such payments tend to far exceed litigation costs of even the most expensive known patent litigation to date, making them suspect by any measure.

Looking ahead, parties to a reverse payment will need to negotiate with a view that their agreement will be scrutinized by antitrust agencies and courts. Since at least 2005, settlements have evolved beyond cash payments to include other forms of consideration. Courts must now articulate how cross-licensing, service agreements and offers to delay authorized generic launches are to be assessed. Carelessly applied, Actavis could open litigation floodgates, dampening R\&D by current and prospective patent owners. With the prospect and payoffs of settlement now tightened, generics could also be less willing to develop cheaper alternatives or challenge patents to bring such alternatives to market. In the United States where patent litigation is considerably higher than in Europe, these risks are more real and the consequences more dire.

Beyond reverse payments, Actavis provides a rare and precious opportunity to move the dialogue on the interface between the patent and antitrust laws beyond mere platitudes. Most patent and antitrust stakeholders agree that both regimes seek to promote competition and innovation. An enduring disagreement remains, however, as to how these goals should be operationalized. The fierce rift between the majority and dissent vividly illustrates this: should we give primacy to visible marketplace rivalry or allow more latitude for private ordering between the settling parties?

Some, like the Court, see patent rights defined by both patent and antitrust policies. Thus a patent's scope, as defined by its claims, the 20 -year monopoly over 
its invention, and dynamic efficiency benefits of exclusion, must be considered together with the impact that the patent owner's activities have on market competition and consumer welfare. This qualified view of patents echoes its earlier decision in eBay v. MercExchange, where it held that patents do not confer an automatic right to exclude but instead need to be considered in the context of broader concerns and the equities of the parties.

Moving beyond the "scope of the patent" test could also invite a reexamination of the patent misuse doctrine. In a patent law defense created to prevent the abuse of patent rights, application rests squarely on the "scope of the patent" formulation. Concern over its vagueness and breadth has led to it being cabined in part by Congress, but mostly shackled by jurisprudence from the Court of Appeals for the Federal Circuit. A measured revitalization may bring relief to antitrust defendants. Courts, wary of the treble damages and private litigation under antitrust laws, may prefer a more graduated response of temporary unenforceability under patent misuse.

Acvatis also invites judges to develop a more sophisticated view of unilateral and concerted conduct by patent owners. Jurisprudence at the interface between patent and antitrust law is muddled and outdated. It is a product of schizophrenic pivoting between condemnation of and deference to patents, and a mutual distrust between patent and antitrust stakeholders. Skeptics like Chief Justice Roberts are rightly concerned that greater antitrust intervention could hurt rather than encourage innovation and competition. But it need not be necessarily so.

According to Michael Carrier, co-author of an amicus brief signed by 118 law, economics and business professors, "Actavis promises to be one of the most important patent/antitrust rulings of all time." He is correct in at least two ways. Described by Robin Feldman as "ground zero" for pharmaceutical development and sales, the impact of Actavis on drug prices and innovation will be felt in the United States and far beyond. In addition to a closer scrutiny of the settlements themselves, Actavis may spur legislative change to allow subsequent generic filers to continue the challenge if the first filer settles. But if that were all Actavis changed, it would still be business as usual, with regional circuit courts going their separate ways and stakeholders speaking over each other.

The true legacy of Actavis lies in the promise of catalyzing those from the patent and antitrust spheres into moving towards a realistic compromise on how the rules that affect them both should look like and function. Writing about Actavis, Shubha Ghosh lamented that

[w] hat keeps the opinion from perhaps being a great one there was [that there was] no consideration of the competing policies with an attempt to reconcile them. While the dissent takes for granted the opposing policies of patent and antitrust, the majority states that this tension is an assumption rather than a reasoned conclusion.

Through debate, experimentation and refinement innate in common law, future cases can craft pieces that will form a coherent analytical framework for the interface between patent and antitrust laws. The effort must be supported by constituents clear-headed enough to look beyond traditional prejudices, who are 
able to translate economic insights into workable legal rules, and who recognize that failure would mean that law at the interface will look a lot like the current state of American politics - divided, dysfunctional and a hotbed for empty rhetoric.

Acknowledgments I am grateful to Mike Carrier, Scott Hemphill, Steve Lee, Mark Patterson, John Richards and Josh Sarnoff for their valuable comments. I thank Sofia Filgueiras and the IIC for the invitation to contribute this Editorial. All errors and omissions remain my own. 